\title{
WestVirginiaUniversity
}

THE RESEARCH REPOSITORY @ WVU

West Virginia Agricultural and Forestry Experiment

Davis College of Agriculture, Natural Resources

Station Bulletins

And Design

$1-1-1958$

\section{Value of creep feeding in production of feeder calves}

C. J. Cunningham

Follow this and additional works at: https://researchrepository.wvu.edu/ wv_agricultural_and_forestry_experiment_station_bulletins

\section{Digital Commons Citation}

Cunningham, C. J., "Value of creep feeding in production of feeder calves" (1958). West Virginia Agricultural and Forestry Experiment Station Bulletins. 423.

https://researchrepository.wvu.edu/wv_agricultural_and_forestry_experiment_station_bulletins/402 @ WVU. It has been accepted for inclusion in West Virginia Agricultural and Forestry Experiment Station Bulletins by an authorized administrator of The Research Repository @ WVU. For more information, please contact ian.harmon@mail.wvu.edu. 


\section{Value of}

\section{CREEP FEEDING}

\section{In Production of Feeder Calves}

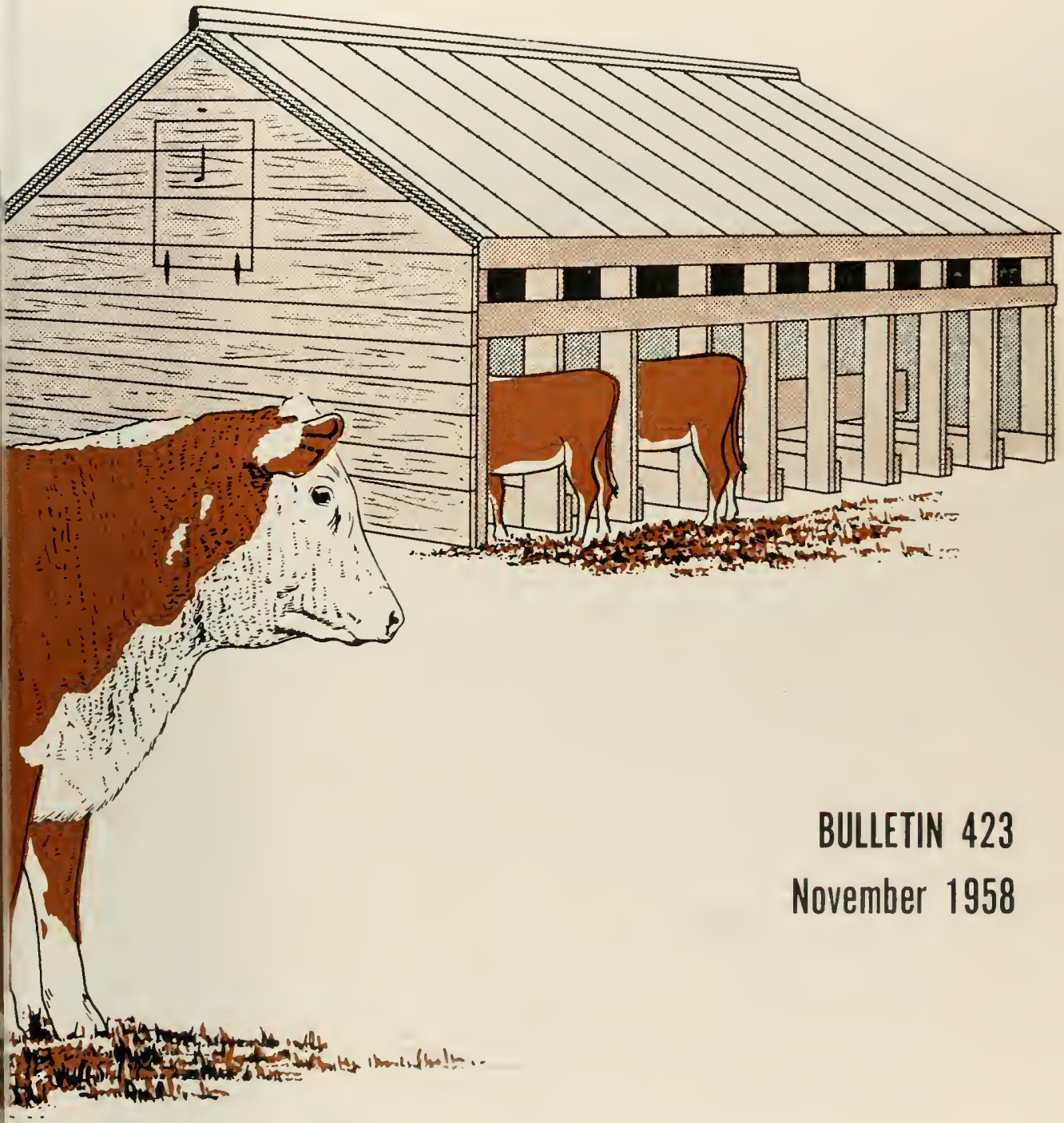




\section{THE AUTHORS}

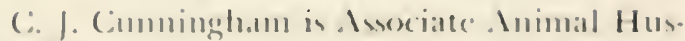
bandman and superintendent of Revmann Memenial Fanms: (. C. Anderson is Animal Hubandman and Profeser and Head of Aumal Husbandre: J. (). Heishman is Asso. ciate Inimal Patholegrist stationed at Reymann Memorial Fanms, Wardemsille; and

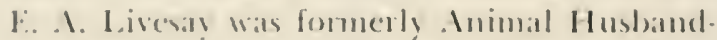
man and Prolesor and Head of Inimal Hus. bandar.

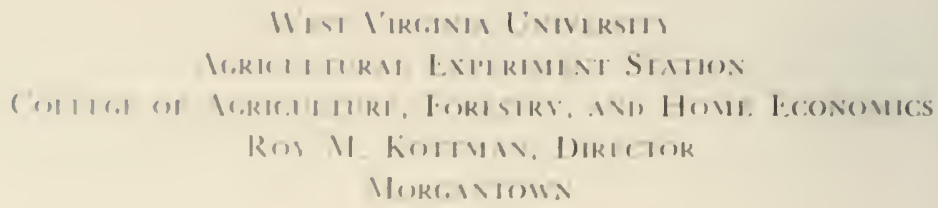




\section{Value of Creep Feeding In Production of Feeder Calves}

\section{J. CUNNINGHAM, G. C. ANDERSON, J. O. HEISHMAN, and E. A. LIVESAY}

\section{Introduction}

THE maintenance of cow herds lor production of feecler calves is one of the major phases of West Virginia's beef cattle industry. West Virginia's high-quality feeder calves have attrated the attention of feeders for many years. Such calves demand a premium, and the dilterence between the price paid lor lancy and choice calves and that paid for calves of lower grade has been great enough to warrant the production of fancy and choice calves.

Many sound practices must be followed to produce calves grading choice or better. The use of a purehred lull of acceptable type. proper winter feeding and management of the bull and of the cow herd are essential for best results. An abundance of good pasture is of equal inportance in the production of high-quality feeder calves.

The feeding value and carrying capacity of many pastures in $W^{y}$ (') Virginia often are reduced during July and August because of low manfall. Accordingly, the amount of milk produced by cons during this period decreases just when the calves need and can use more milk to bent advantage. In addition, the call cammot obtain as much feed value lrom the pasture as it shomld for economical and rapid gains. As a resulte many calses are mable to develop at they should and are sold grading good or lower when they conld have graded choice or better had sullicient leed been avialable.

With these factors in mind, trials were started in the spring of 1951 to determine the ellect of supplementary feed upon the weaning weight and grade of leceler calves.

\section{The Trials}

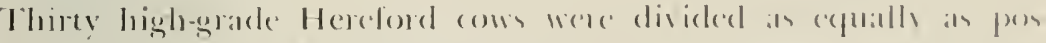

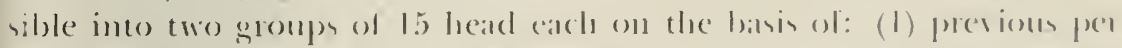
formanse, that is, regularity in calving, and glade and weight of call all weaning: (2) age: (3) weight: and (1) breceling. Both gromp were wintered together on a 1 attion of mixed hat and gliss-legume vilage we as to gain between 75 and 100 poumds. 


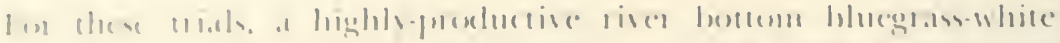

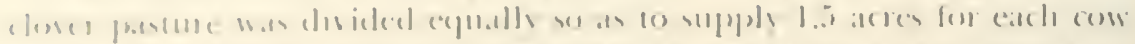

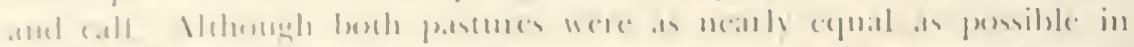

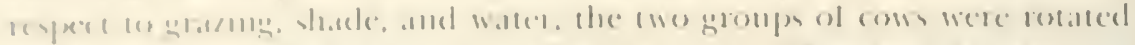

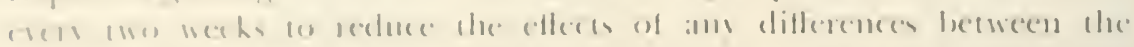

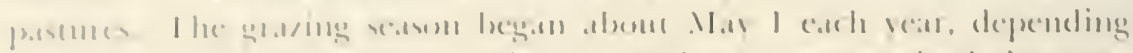

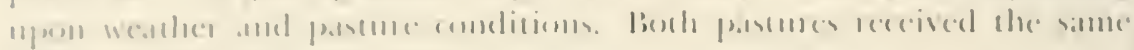

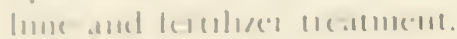

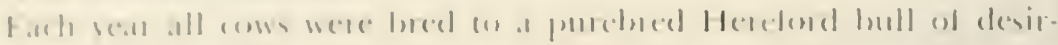

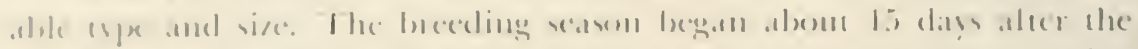

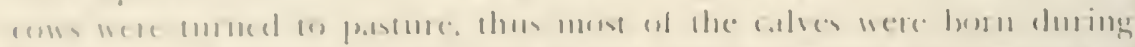

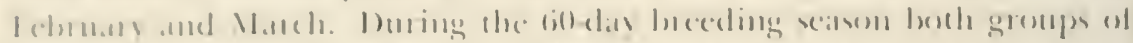

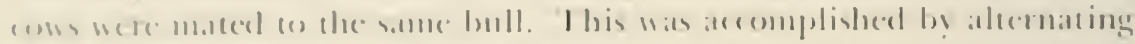

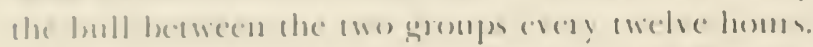

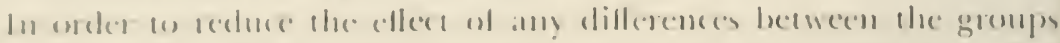

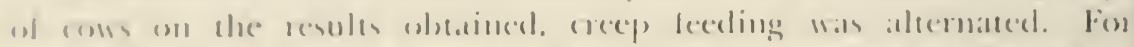

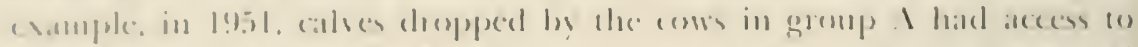

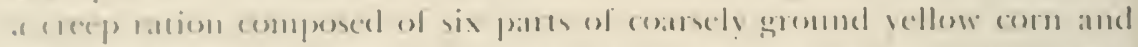

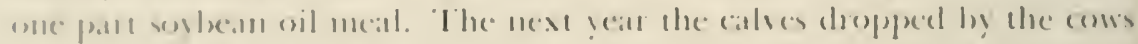

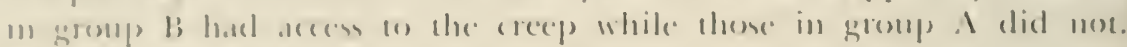

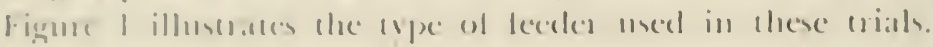

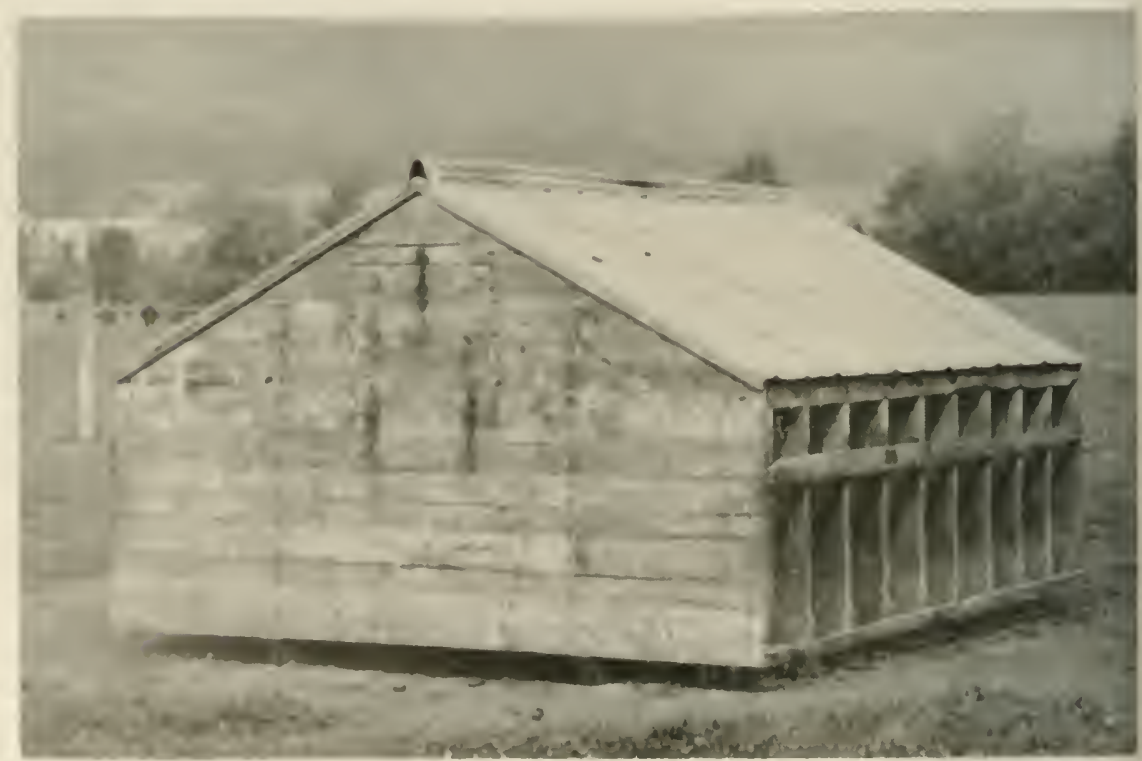

Figure 1. The creep used in these trials can be easily and cheaply built and can be moved from one pasture to another. Plans may be obtained from your county agricultural agent or by writing to the Department of Animal Hus. bandry. West Virginia University. Morgantown. 
Cows which failed to calve or died during the trials were replaced with cows as nearly the same as possible in respect to age, weight, performance, and breeding.

All calves were weighed at the beginning of the creep-feeding period and every 28 days thereafter until weaning, except in 1955. In that year the calves were weighed on the first three days of creep feeding and on each of the last three days of the trial. The averages of these weights were used as the beginning and ending weights respectively.

Fresh feed was adcled to the creep each week (more often if needed) so that the calves had all they wanted to eat. Feed cost figures are based on actual prices paid for feed.

The average weaning age for the five trials was $21-1$ day's. At weaning the calves were graded by a conmittee of three men who were familiar with the official feeder calf grades of the United States Department of Agriculture (Figures 2, 3, and 4). The average of the grades given to each calf by the committee and the average price paid for that grade at all West Virginia Demonstrational Feeder Calf Sales held that year, were used to determine the value of each calf. The results presented have not been adjusted for age or sex.

\section{Results}

The influence of creep feeding upon grade, daily gains, and weaning weight is shown in Table 1 . Creep feeting inproved the average feeder calf grade by approximately one full grade, from good to choice.

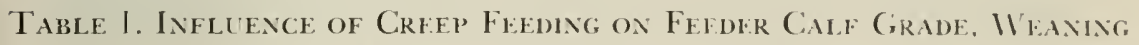
WEIGHT AND RATE OF GaIN

(FIVE-YEAR SUMMary)

\begin{tabular}{|c|c|c|c|c|c|c|}
\hline \multirow[b]{2}{*}{ GRADE } & \multicolumn{3}{|c|}{ No Creep Feedixg } & \multicolumn{3}{|c|}{ CRERT Fl:D } \\
\hline & $\begin{array}{l}\text { STEERS } \\
(\therefore 6)^{*}\end{array}$ & $\begin{array}{l}\text { HEIFERS } \\
\text { (3S) }\end{array}$ & $\begin{array}{c}\text { STEERS } \\
\& \\
\text { MEIFERS } \\
(74)\end{array}$ & $\begin{array}{l}\text { STEERS } \\
(42)\end{array}$ & $\begin{array}{l}\text { IIEIFERA } \\
\text { (:Z) }\end{array}$ & $\begin{array}{c}\text { SFEERS } \\
\text { E } \\
\text { (IEIFIRS } \\
(\tau f)\end{array}$ \\
\hline Falley & 1 & 2 & $: 3$ & $1 t i$ & $\because$ & 25 \\
\hline$\ldots \ldots \ldots \ldots \ldots$ & 17 & 17 & $: 14$ & 24 & 211 & 14 \\
\hline Good & 17 & 18 & $: 15$ & $\ddot{z}$ & $\therefore$ & $\bar{i}$ \\
\hline Medium & 1 & 1 & 2 & 0 & "1 & $" 1$ \\
\hline Ar. Grade** & 2.501 & 2.53 & $2 . .51$ & $\therefore, 3::$ & $: 1,1: 1$ & $: \because: 7$ \\
\hline Av. Injtial Wt.-Lbs. & 209.5 & $20 x .2$ & 2018.5 & 2015..! & 21111.9 & 211.5 .1 \\
\hline Av. Euding Wt.-Lbs. & 125.4 & $1: 2(i, 1)$ & $127: 2$ & 511.1 & $11: 4.2$ & $14: 3.2$ \\
\hline Av. Total Gain-Lbs. & 218.9 & 217.5 & $\because 8.3$ & $: \because 12 . . \overline{1}$ & Zßis.: & $3 \times 7.7$ \\
\hline Av. Daily Gains-labs & 1.7 & 1.6 & $1.1: 7$ & $\because \because$ & 21 & $\because 2$ \\
\hline
\end{tabular}

Calves were creep fed an average of $1: 1$ days and weaned at an arrake age of 211 days.

* Numbers in parentheses represent number of calves in trials.

**ancy-4; Choice-3; Good-2; Medium-1. 

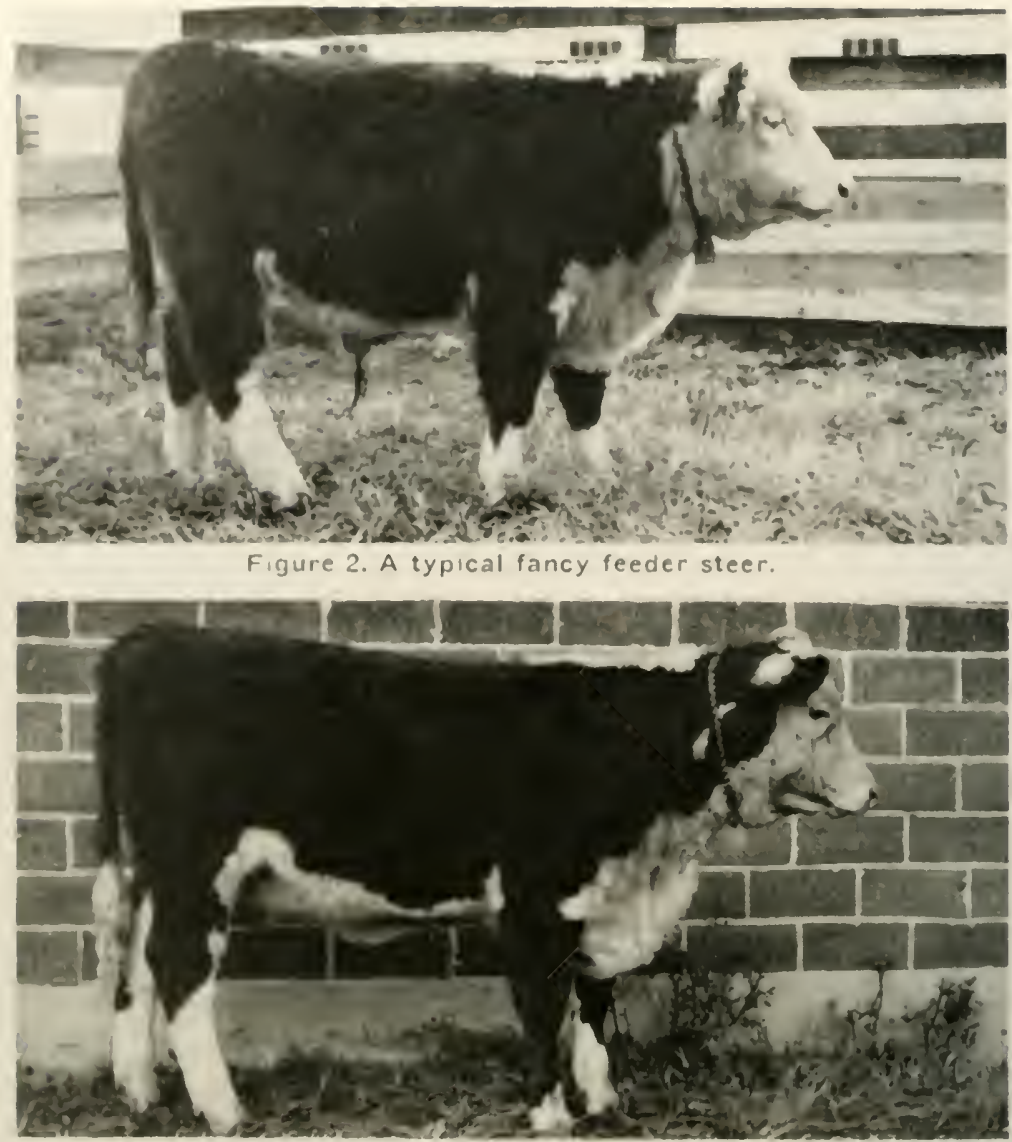

Figure 3. A typical choice feeder heifer.

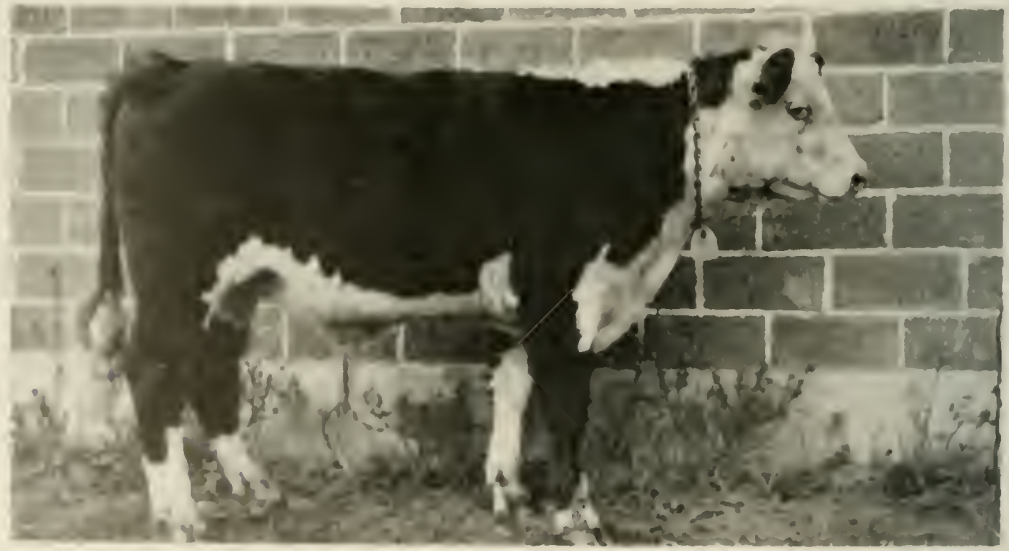

Figure 4. A typical good feeder steer. 
In addition, creep leeding increased daily weight gain b) 0.6 pounds in the alse of the steer and 0.5 pounds in the heifers. Is a result, the crep-fed steers and heifers weighed 8.8 and t.3 pounds more respectively at weaning time than calves which did not receive supplementas feed. Moreover, the creep-led calves were unuch more uniform in weight and appearance. (Figures 5 and (b.)

The amount of feed eatcii and leed costs ores the five-year period are given in Table 2. The areage amount of feed comsmmed be each calf was 519.4 poumcls, but the amomm eaten varied comsiderably from year to year. This diflerence was related to the guality of pasture. which in tum was influcenced by moisture conditions. The rainlatl disurbution chant, Table 1, Ippendix, shows that randall was panticulats low in 195\%. 1)uring this year the calves consmmed the most feed, and during 1955, when mosisture was plentiful, the alves comsuned the smallest amount of feed.

It is not smprising then that the effect of creep leeding upon gatin and weight was greatest in vears when moisture was limited. This is clearly shown in Appenelix Tables II, III, Ir, Y and V'I, which show results for cach year.

Each year creep feeding improved the grade and increased the weaning weight. Is a result, crep-fod ralves brought a higher price per hundred weight and per hata. When the results of all five years are averaged, Table s, the selling price per hundred reight increased by $\$ 3.20$ for creep-fed steers and $\$ 2.10$ for the crepe-fect heifers. This increase in value because of improvement in grade, along with the increase in weaning weight, increased the vilue per head of the steers by $\$ 38.19$, and $\$ 19.15$ for the heiles.

The average yeatly cost of creep feed per call was $\$ 20$. 41 . Feed consumption and utiliation are considered to be the same lor seco and heifers of the age and weight used in these trials. Considering then that the feed costs for stecr and heiler calves were the sime, crep fecding increased net returns from the steers four out of fire years but onls increased net returns from the heilers one year out of the live. (On dhis basis, creep feeding increased the average yearly return from steer aldes

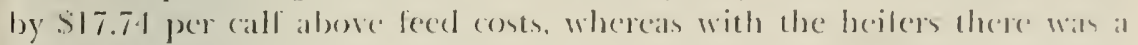
loss of $\$ 1.29$ per head.

\section{Discussion and Summary}

Five trials were conducted with wo grouph of 1.5 high-grade Here ford cows and their alves to determine the value of ereep feeding in the production of feeder calves. The coms and calven gratad well-fertilifed, bluegrass-white clover pastures which provided aboul 1.5 ander 


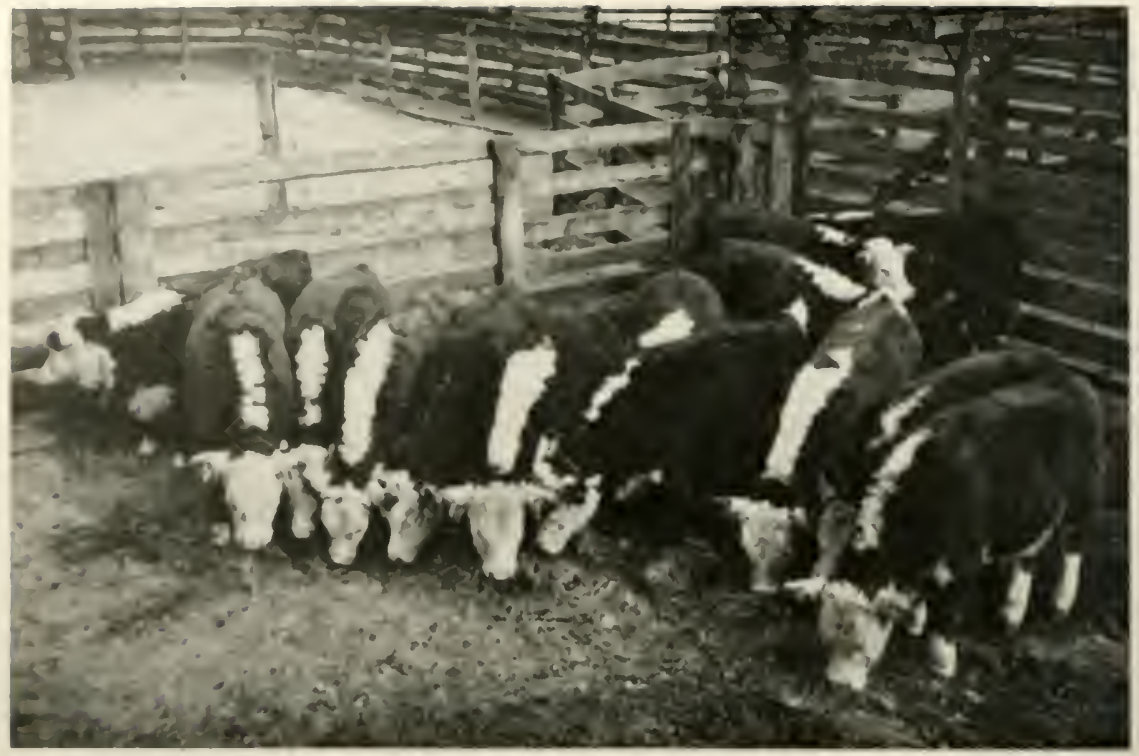

Figure 5. Typical group of creep.fed calves at weaning. Notice uniform size of calves compared to those shown in Fig. 6 which did not receive additional feed. Average weight-476 lbs.

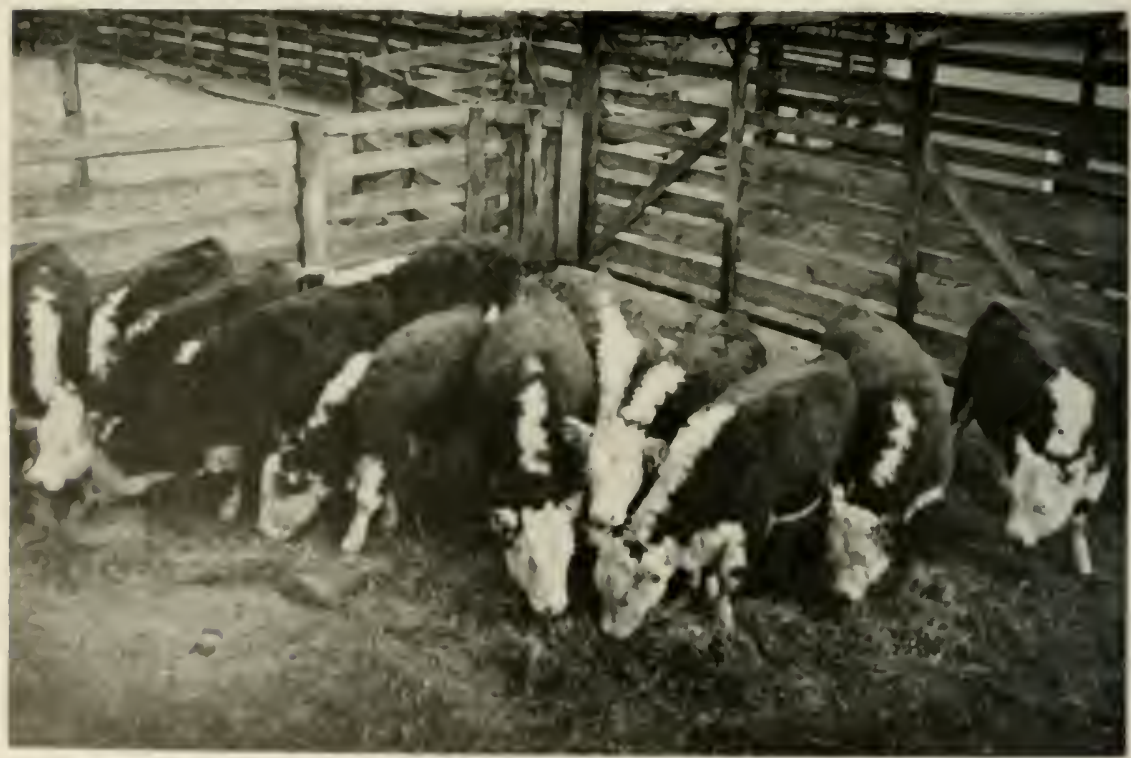

Figure 6. These calves were not creep fed. Notice the lack of uniformity and bloom when compared with the creepfed calves shown in Figure 5. Average waight -129 ibs. 


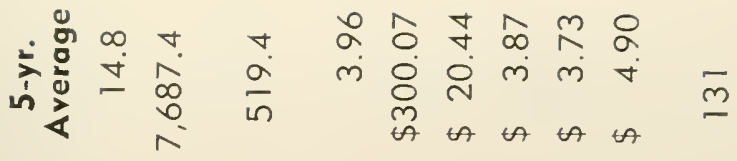

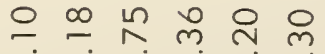

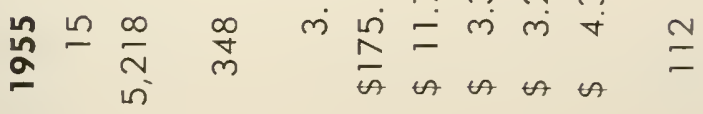

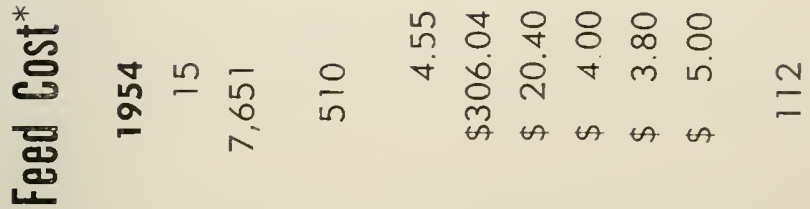

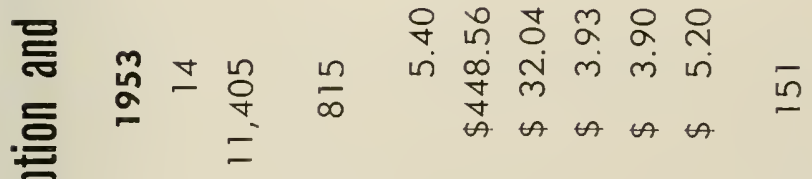

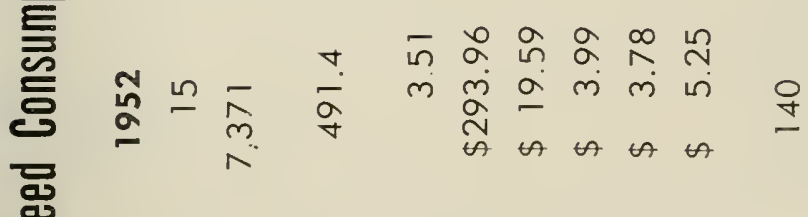

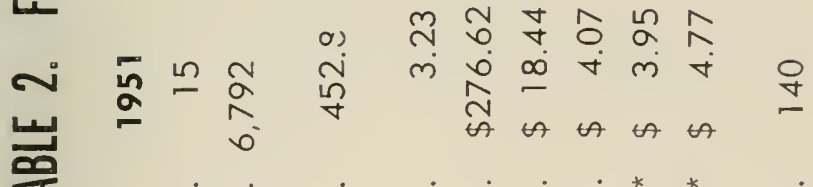

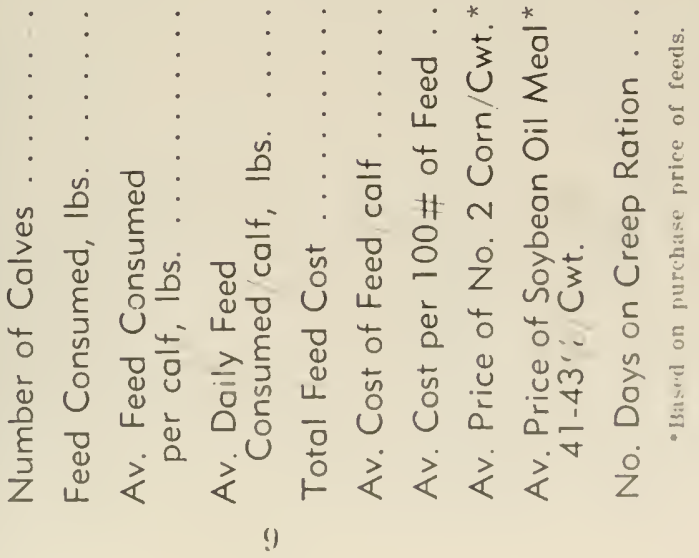




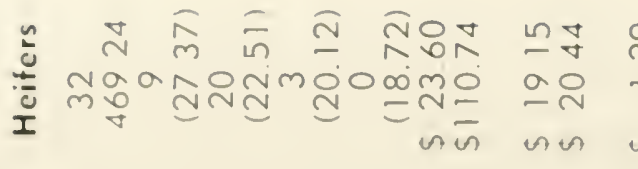

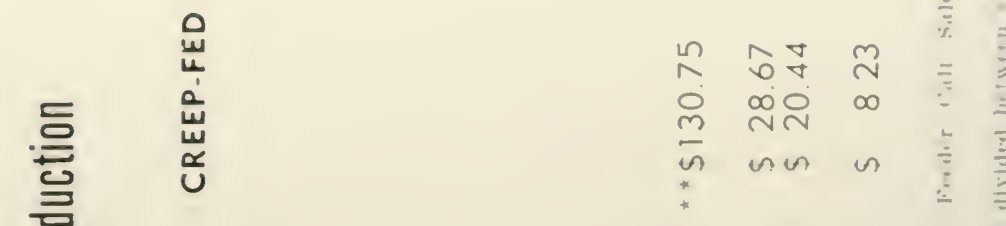

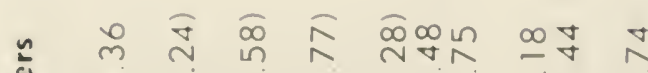
ปั 焉 in $\bar{n}$ en in in

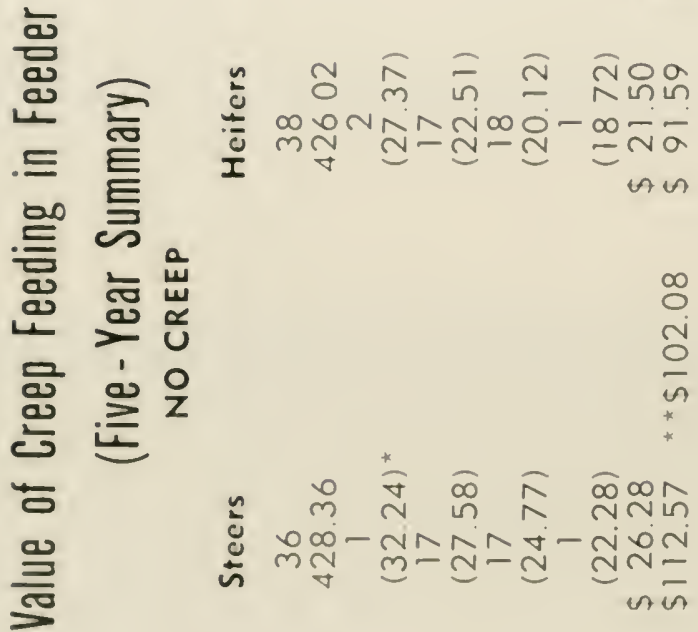

罢

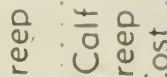

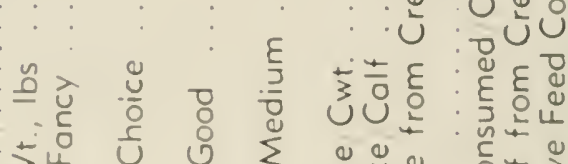

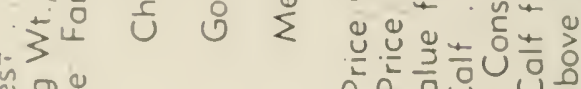

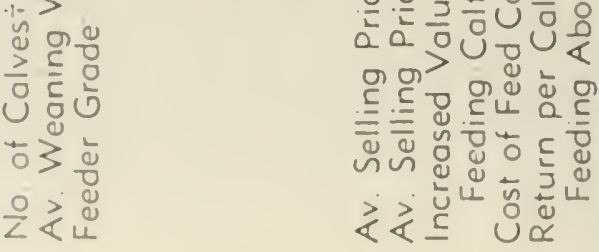


per cow. Each year calves from one gromp of cows had access to a creep ration consisting of six parts coarsely ground yellow corn and one part soybean oil meal.

Creep feeding improved the arerage feeder calf grade from good to choice, and increased the average weaning weight of the steers by 83 pounds and that of the heifers by 43 pounds. This improvement in grade and increase in weight resulted in an average increase in value of $\$ 38.19$ per head for stcers and $\$ 19.15$ for the heifers.

Calves were creep led for an average of 131 days each year. During this period they consumed an average of 519.4 pounds of feed per head at a cost of \$20.44.

Grazing conditions, as affected by the amount and distribution of rainfall, influenced the response of the calves to creep feeding and the amount of focd eaten. When moisture was insufficicnt, the calves atc more of the creep feed than when there was sufficient rainlall and grazing was good.

When the \$20.41 feed cost is charged against cach calf, creep feeding increased the average yearly net returns per stece by \$17.7. However, in the case of the heifer there was a loss of 51.29 per head.

The results obtained in these trials (considering that the calf crop) is equally divided between steers and heifers), shows that creep feeding increased the yearly retum per call above leed costs by $\$ 8.23$.

\section{Acknowledgement}

The cooperation of Mr. B. F. Creech and Mr. Joseph linch, Extension Animal Husbandmen, in grading the calves is appreciated. "The photographs were taken by Mr. David Creel, Station Photographoler. 

APPENDIX 


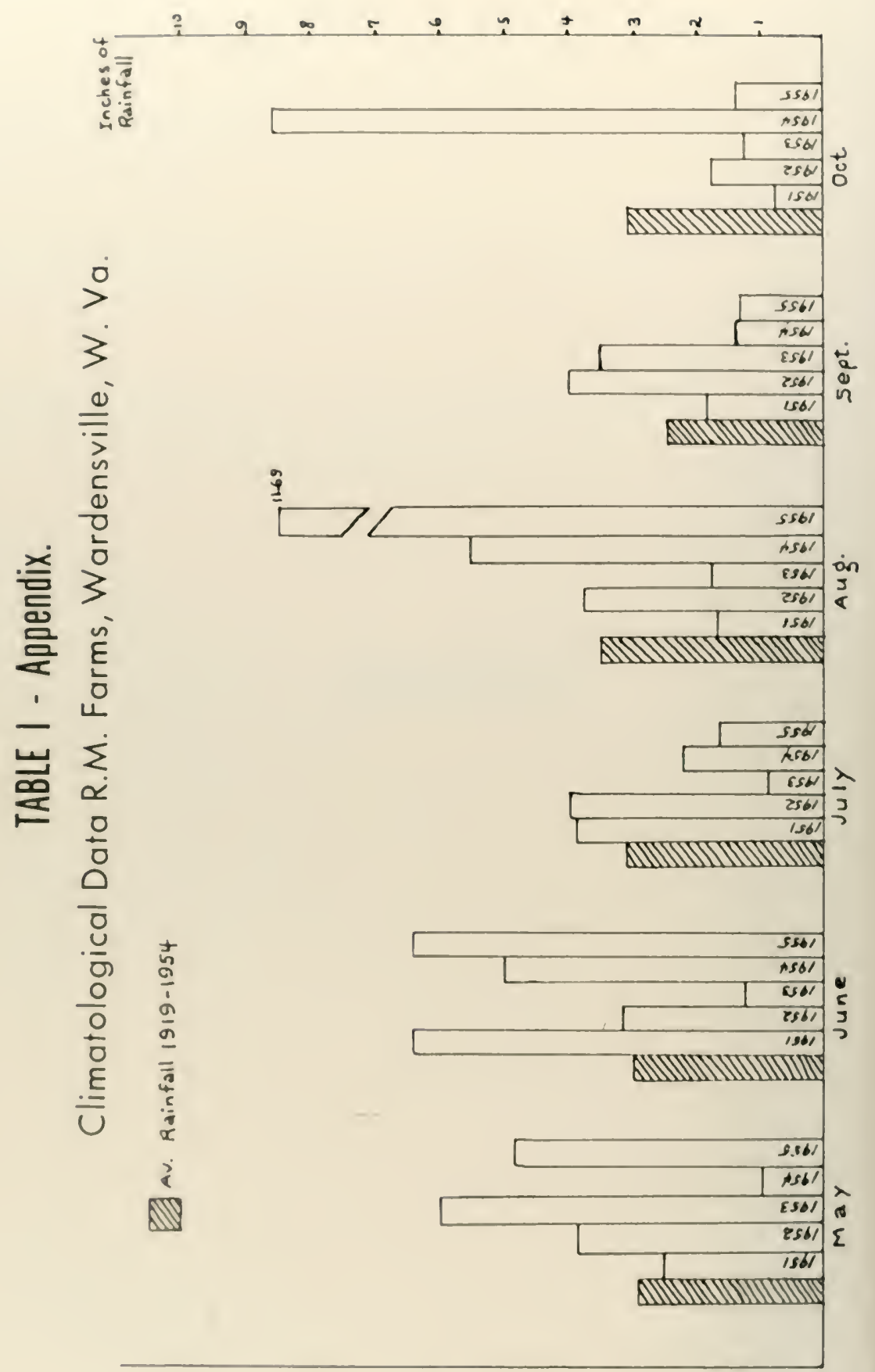




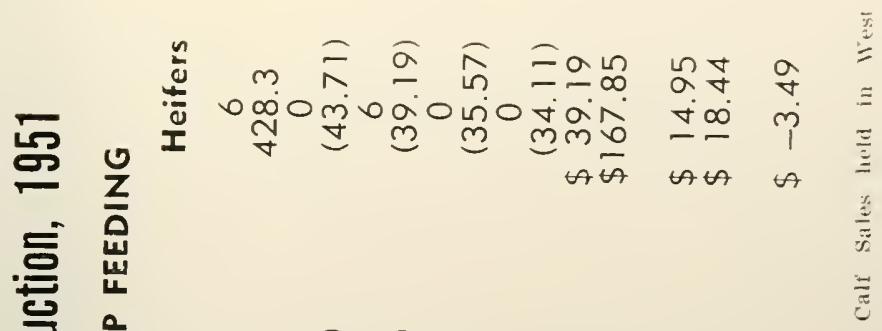

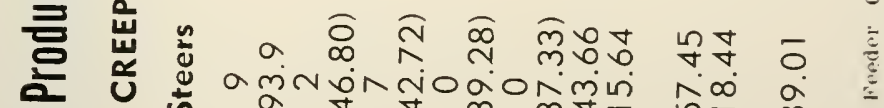

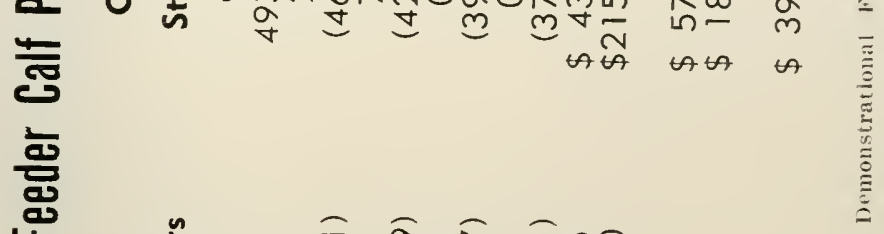

도 늏

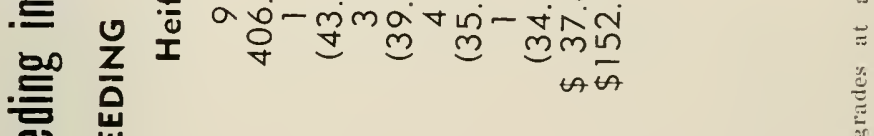

व

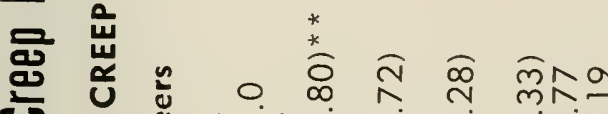
nकo

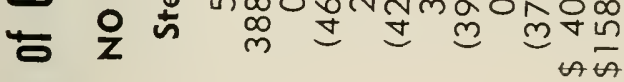

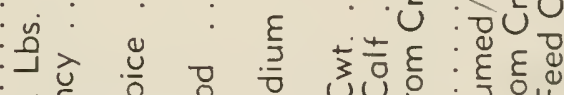

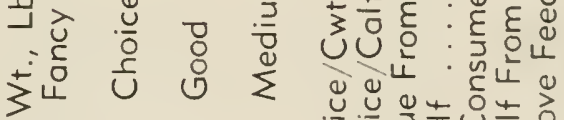

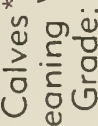
$\therefore=\frac{1}{2} \frac{0}{0} \div$ ล ล णु काष केष का ᄃำ

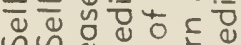
$43 \frac{1}{0}$

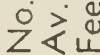
ทง⿺辶⿻ 丶 《主 


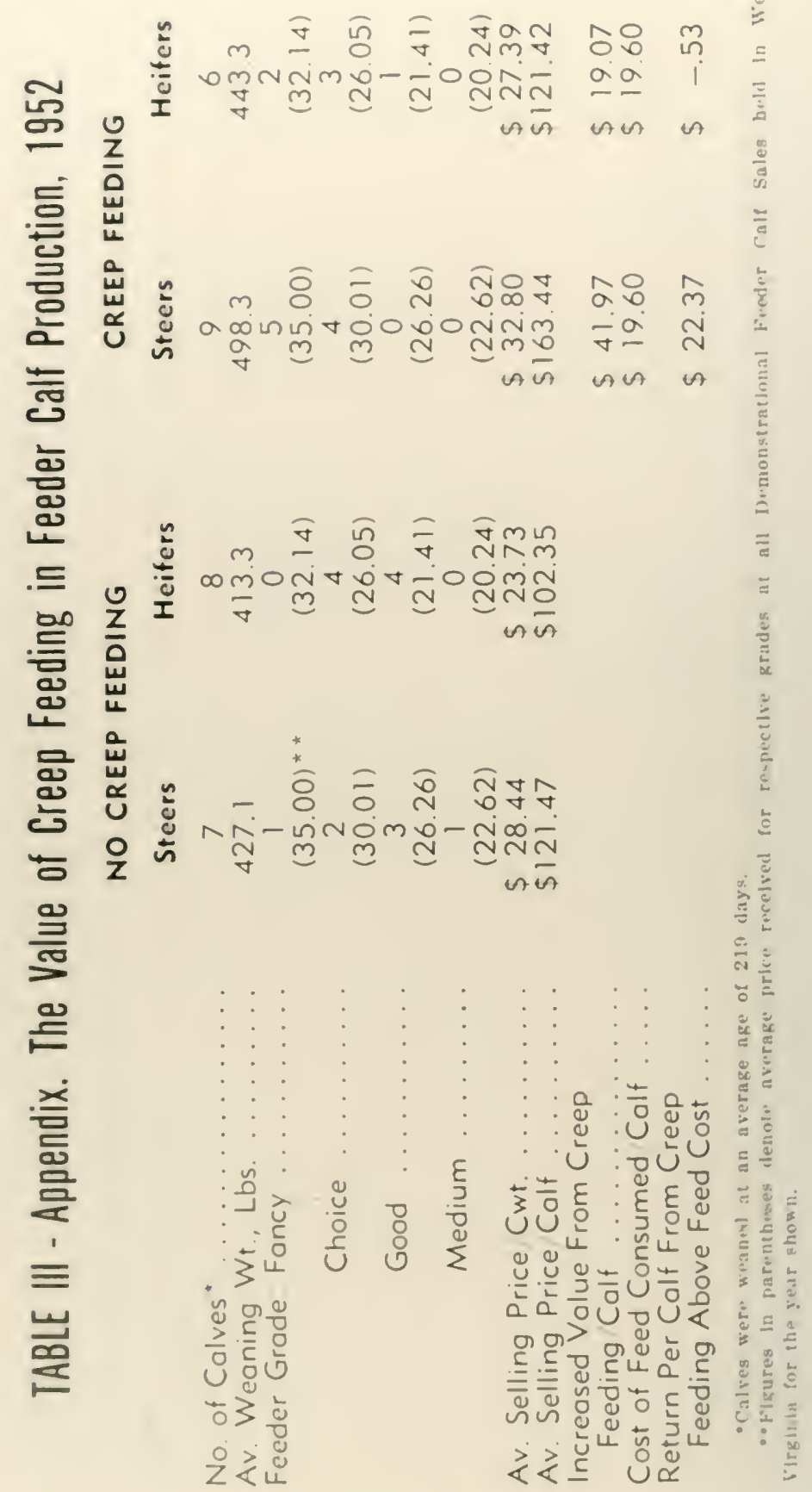




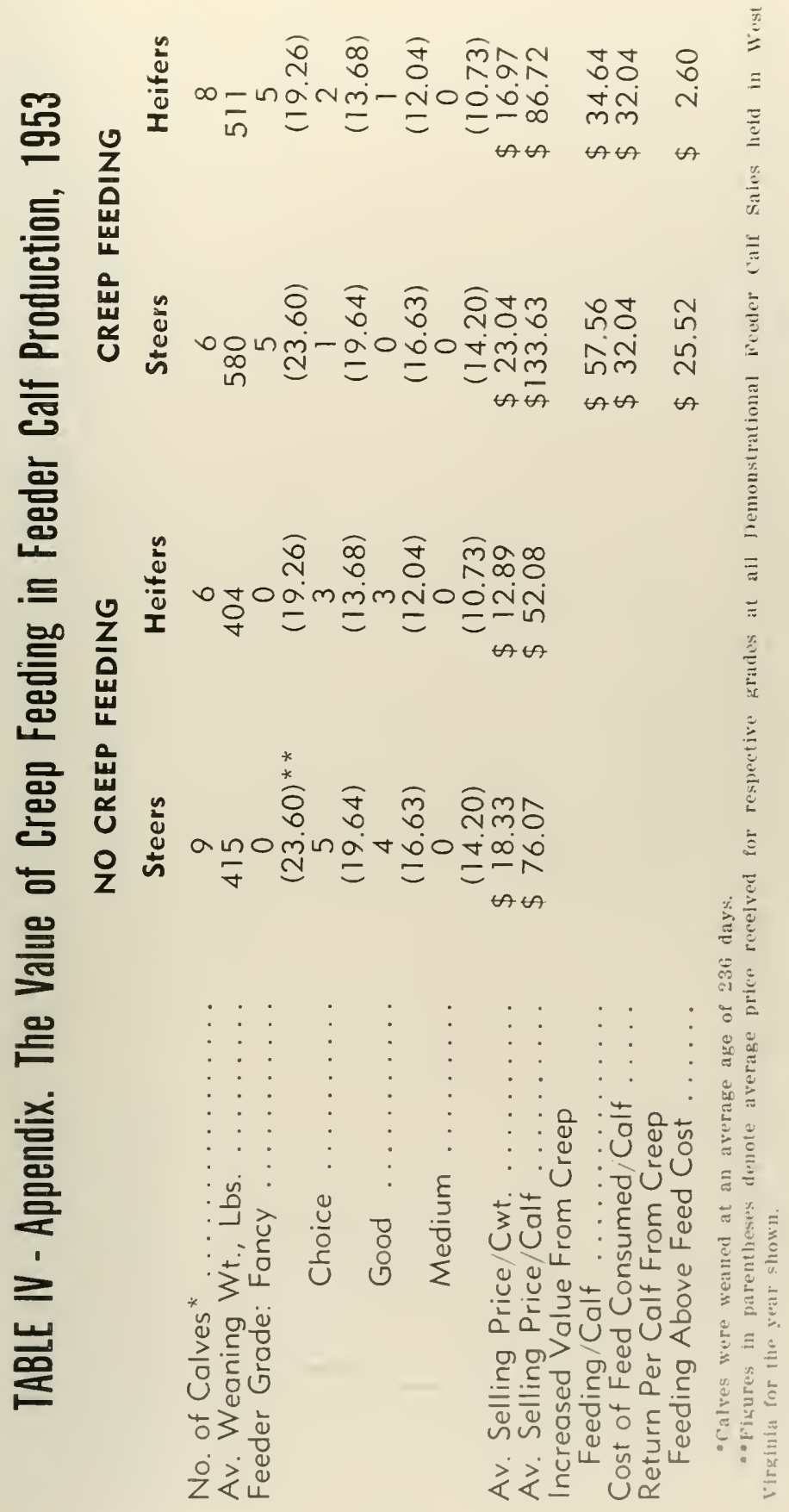




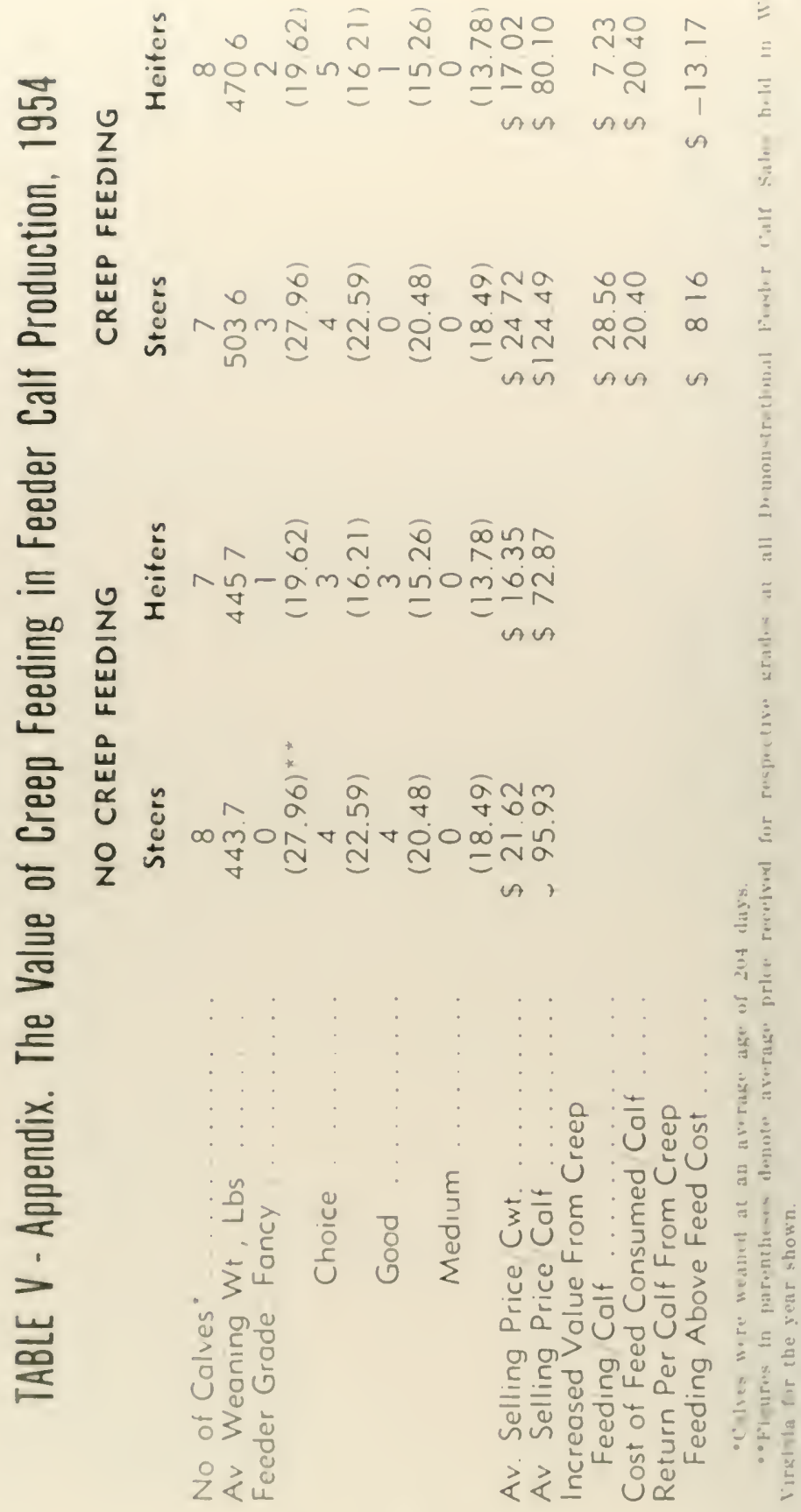




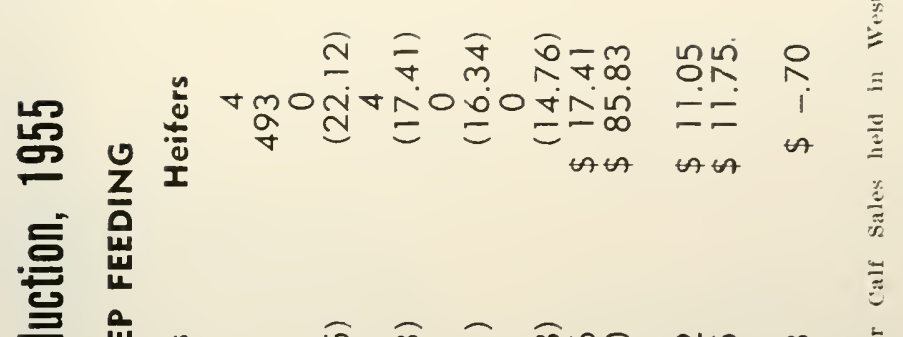

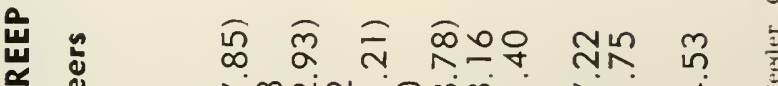
ํํำ

宁

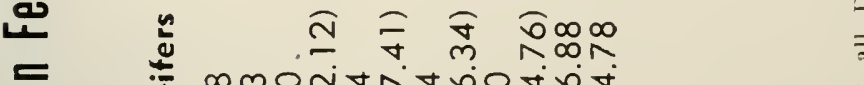

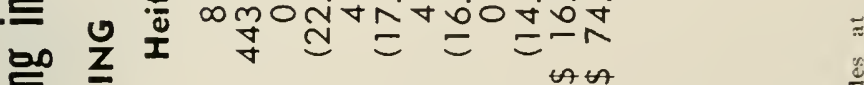

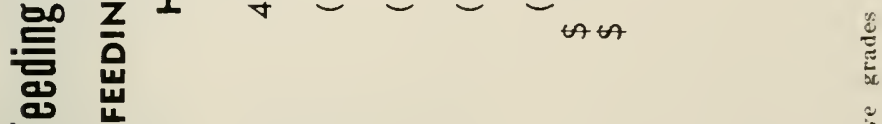

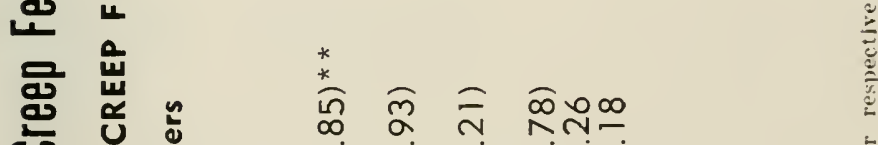

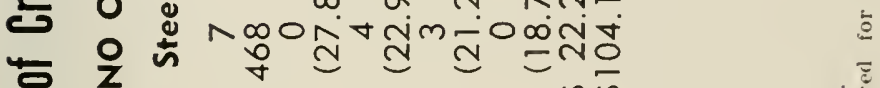

Q

$\cdot \cdot \cdot \cdot \cdot 5$

를

를

- 능 $\frac{2}{2}$

- ¿. U⿺辶寸

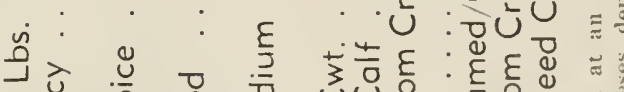

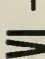

३ 4 U 0

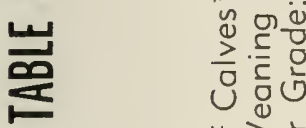

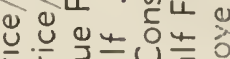

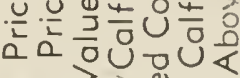
이 के थे ण

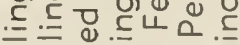

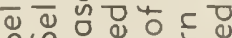
ทงष i $>0$

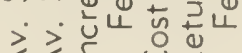

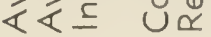


